\title{
Denial of Child Maltreatment Histories among Male Adolescent Offenders
}

\author{
Aslı Cennet Yalım ${ }^{1}$ and A. Ufuk Sezgin ${ }^{2 *}$ \\ ${ }^{1}$ University at Buffalo, School of Social Work, Buffalo, NY, USA \\ ${ }^{2}$ Istanbul University, Istanbul Faculty of Medicine, Department of Forensic Medicine, Istanbul Turkey
}

\begin{abstract}
This paper aims to explore relationship between childhood maltreatment histories and denial of male adolescent offenders who are imprisoned for violent criminal behaviors. The study group consists of 235 male adolescents between the ages of 15 and 18 in İstanbul Bayrampaşa $\mathrm{H}$ Type Prison affiliated to the Ministry of Justice. According to the results, one hundred and thirty-seven children have child abuse and neglect (CAN) histories and there is no significant relationship between violent criminal behavior and being exposed to CAN. However, responses of adolescents indicate that they tend to deny CAN histories when being asked direct questions regarding violence compared to indirect questions. Additionally, the results of Childhood Trauma Questionnaire (CTQ)'s Minimization/Denial subscale show that $71 \%$ of the study group has sufficient scores for possible underreporting of maltreatment. This study can provide guidance to clinicians, who are going to conduct a study on adolescents with maltreatment histories, regarding possible tendency of denial.
\end{abstract}

Keywords: Delinquency, CTQ, Denial, Child Maltreatment, Adolescents.

\section{INTRODUCTION}

In earlier times, the child was considered as the property of his or her parents and there was no law to protect children against CAN. Even though this view has changed over time, the belief about the responsibility of parents on treatment of children remains the same in most cultures (Ife 2008).

Violence against children by parents or caregivers takes place in the privacy of domestic life. Social and cultural norms that encourage violence and physical punishment towards children have an effect in contributing to child maltreatment (World Health Organization 2006). Studies demonstrate that Turkish families use this type of violence to discipline their children. Mild level of violence is not considered as a major problem among Turkish families. As a result, children growing up in abusive households likely develop violent problem-solving styles in their adulthood (Bilgin et al. 2004; Ovacık 2008). The study on Turkish women show that those who have history of CAN are at increased risk of abusing their own children. Women who were abused or were witnesses of abuse during their childhood perform physical abuse toward their children more than the ones without such a history (Caykoylu et al. 2011).

Fear of negative consequences and of not being believed may make children unwilling to talk about

*Address correspondence to this author at the Istanbul University, Istanbul Faculty of Medicine, Department of Forensic Medicine, Istanbul Turkey; Tel: 90216 3616176; E-mail: usezgin@istanbul.edu.tr
CAN experiences. If the perpetrator is a family member, the child is afraid of punishment as a consequence of their disclosure (Leander 2010). This leads to particular difficulties in designing strategies for prevention, since the perpetrator is at the same time the source of nurture for the child (WHO 2006).

Children exposed to violence tend to suppress or completely avoid painful thoughts and feelings related to their experiences (Gil 1991). Denial is a defense mechanism that refuses the meanings of a situation, partially or completely. A threatening and unacceptable situation is perceived as though it does not exist. Ego reduces the anxious and painful emotions of the reality. Denial is an acceptable response until a certain degree, particularly in trauma, abuse, and grief cases (Grinberg 1961). Victims deeply suffer from anxiety, feelings of abandonment, and hopelessness as a result of the exposed to violence. Children who experience these feelings, in general, are expected to use defense mechanisms of denial (Aktepe, Kandil, and Topbaş 2005; Greydanus and Calles 2007). While working with a child who is the victim of violence, professionals must take the level of denial into consideration. When clinicians start to distinguish the level of denial, the knowledge about the actual level of violence can be successfully attained. Violence by itself is a hurtful experience for a child. Thus, clinicians need to have a tolerant and persistent approach in helping children with histories of CAN (Hanks \& Stratton, 2007).

The study on 301 adult male felons shows that $68 \%$ of the sample reported some form of CAN history. Violent felons in the study reported significantly more 
history of neglect than non-violent felons (Weeks and Widom 1998). In another study by Haapasalo and Moilanen (2004), self-reports and official criminal record data on violent criminality of young prisoners determine that they have history of physical abuse during their childhood. The study identified that some participants have a tendency to minimize and deny their experiences. Hence, the number of prisoners with abuse experiences is underreported and data on CAN histories of prisoners does not reflect actual numbers. In addition, the study by Widom and Shepard (1996) demonstrates that approximately $40 \%$ of individuals with documented histories of physical abuse did not report their experiences. The data from official reports of individuals who were physically abused, sexually abused, or neglected about 20 years ago were followed up along with a control group. The reasons of underreporting of CAN histories were embarrassment, protecting parents, a sense of having deserved the abuse, a wish to forget the past, or lack of rapport with the interviewer.

Summit's model of the 'Accommodation Syndrome' allows clinicians to recognize level of denial among abused children. This model helps professionals to understand how children feel helpless, maintain the secret, take responsibility, and feel guilty. If clinicians remain patient during this process, children might begin to speak up their experiences, slowly but eventually. At this point, putting any pressure on children can cause children to retract, which is a part of the accommodation syndrome. With this model, clinicians can realize level of denial (Hanks and Stratton 2007; Summit 1983).

The aim of this study was to explore the childhood maltreatment histories of male adolescent offenders imprisoned for violent criminal behavior. The hypothesis of the study was that there is a significant relationship between violent criminal behavior and being exposed to violence during childhood. Although the data did not support the hypothesis, it was determined that participants have a tendency to deny their experiences of CAN. This paper will describe the findings related to denial of violence, which can provide guidance to clinicians who work with children with CAN histories.

\section{METHOD}

\section{Participants}

The study group consists of 235 male children, between the ages of 15 and 18, located in the İstanbul
(Bayrampaşa) H Tipi Kapalı Ceza İnfaz Kurumu (H Type Prison) affiliated to the Ministry of Justice. $\mathrm{H}$ type prison is a closed type prison that requires maximum security and does not allow any interactions with the outside world. Data were gathered in two sessions through survey method.

\section{Measurements}

\section{Demographic Information Form}

This form was developed by the authors to gather information regarding socio-demographic characteristics, family experiences, and crime information of the participants.

\section{Childhood Trauma Questionnaire (CTQ)}

CTQ is a 28-item standardized self-report measurement tool, developed by David P. Bernstein in 1995, to measure history of abuse and neglect in childhood. It determines five types of childhood maltreatment; physical abuse, sexual abuse, emotional abuse, physical neglect and emotional neglect (Bernstein \& Fink, 1998). The Turkish version of CTQ was tested for reliability and validity (Şar, Öztürk, and İkikardeş 2012).

The CTQ also includes a three-item Minimization/Denial scale indicating the potential underreporting of abuse and neglect experiences. These three items are; "there was nothing I wanted to change about my family", "my childhood was perfect", and "my family was the best in the world". The three items comprising the Minimization/Denial scale are dichotomized ("never" $=0$, all other responses $=1$ ) and summed; a total of one (1) or greater suggests the possible underreporting of maltreatment (Bernstein and Fink 1998; Villano et al. 2004).

\section{Statistical Analysis}

Results related to the demographic variables are presented in the descriptive tables. The chi-squared test was run to examine the relationship between the violent criminal behavior and CAN. The analyses in this study were performed using the SPSS 17.0 program.

\section{RESULTS}

The demographic information about the participating adolescents is shown in Table 1. Accordingly, 32.5\% of the participants are between the age of 15 and 16 , and the remaining $67.5 \%$ are between the age of 17 and 18. $60.9 \%$ of participants did not attend a school before 
committing a crime. In addition, $92 \%$ of the adolescents have employment history prior to prison.

Table 1: Demographic Information*

\begin{tabular}{|c|c|c|}
\hline & & $\mathbf{N}$ \\
\hline \multirow[t]{3}{*}{ Age } & $15-16$ & 72 \\
\hline & $17-18$ & 150 \\
\hline & Total & 222 \\
\hline \multirow{3}{*}{$\begin{array}{c}\text { Living with parents prior to } \\
\text { prison }\end{array}$} & Yes & 202 \\
\hline & No & 33 \\
\hline & Total & 235 \\
\hline \multirow{3}{*}{$\begin{array}{l}\text { Place for living prior to prison } \\
\text { (if not with parents) }\end{array}$} & Street & 15 \\
\hline & Indoor - Dormitory & 14 \\
\hline & Total & 29 \\
\hline \multirow[t]{3}{*}{ School attendance } & Yes & 92 \\
\hline & No & 143 \\
\hline & Total & 235 \\
\hline \multirow[t]{3}{*}{ Previous work experience } & Yes & 216 \\
\hline & No & 18 \\
\hline & Total & 234 \\
\hline
\end{tabular}

*Participants who did not respond were not included.

The questions about CAN histories include both verbal and physical violence. Accordingly, $17.9 \%$ of the parents of participants engage in verbal violence while that percentage increases to $21.5 \%$ for physical violence, as shown in Table 2. However, there were

Table 2: Child Maltreatment Information

\begin{tabular}{|c|c|c|}
\hline & & $\mathbf{N}$ \\
\hline \multirow{3}{*}{$\begin{array}{l}\text { Insult, humiliation and/or threat } \\
\text { in the family }\end{array}$} & No & 193 \\
\hline & Yes & 42 \\
\hline & Total & 235 \\
\hline \multirow{3}{*}{$\begin{array}{c}\text { Physical violence including } \\
\text { slapping, pushing, kicking in the } \\
\text { family }\end{array}$} & No & 183 \\
\hline & Yes & 50 \\
\hline & Total & 233 \\
\hline \multirow{5}{*}{$\begin{array}{l}\text { Frequency of violent behavior } \\
\text { (if occurring) }\end{array}$} & Few in a year & 106 \\
\hline & Few in a month & 40 \\
\hline & Few in a week & 24 \\
\hline & Everyday & 9 \\
\hline & Total & 179 \\
\hline \multirow{5}{*}{$\begin{array}{l}\text { Person(s) being exposed to } \\
\text { violence in the family }\end{array}$} & Self only & 86 \\
\hline & Siblings & 32 \\
\hline & Mother & 14 \\
\hline & Self and relatives & 14 \\
\hline & Total & 146 \\
\hline
\end{tabular}

some contradictory responses. As shown in Figure 1, a total of 179 children responded to the question on frequency of CAN. The corresponding distribution of the frequency was $59.2 \%$ (few in a year), $22.3 \%$ (few in a month), $13.4 \%$ (few in a week), and $\% 5$ (everyday). Moreover, a total of 146 children responded when the question was asked about family members who were exposed to the violence. $58.9 \%$ of these children responded as self. These two question types are defined as indirect questions since they do not inquire if being exposed to violence directly, but instead, the frequency of violence and members exposed to violence in family. These findings show that the participants tend to deny the exposed violence when questions related to violence are asked directly, compared to asking indirect questions.

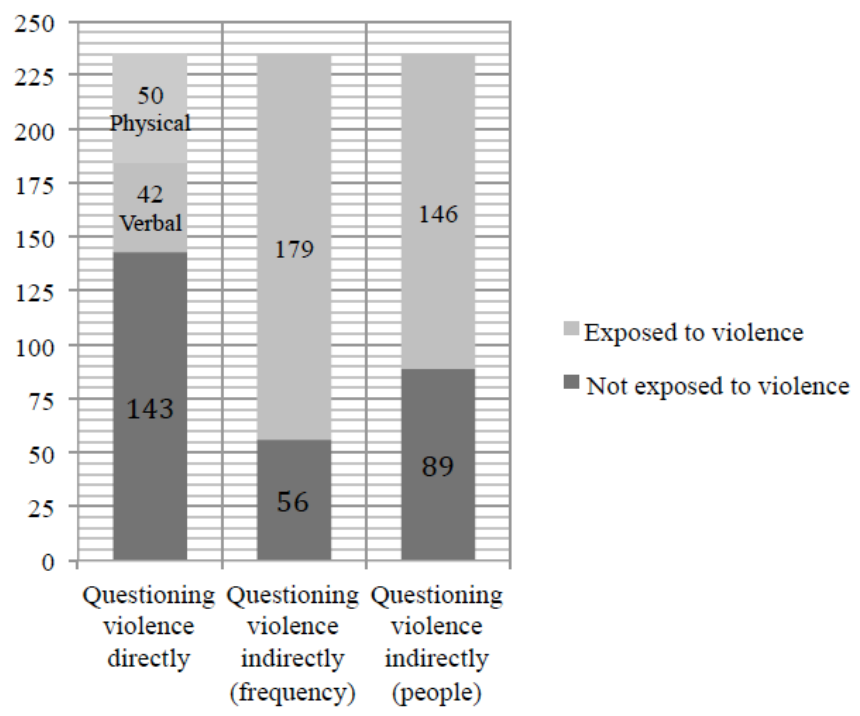

Figure 1: Responses based on question types.

Additionally, The CTQ Minimization/Denial subscale demonstrates that $71 \%$ of the sample group (166 participants) has a minimization/denial score of 1 or above. This finding suggests the possible underreporting of maltreatment.

Table 3: CTQ Minimization/Denial Sub-Scale

\begin{tabular}{|c|c|c|}
\hline \multirow{2}{*}{ Minimization/denial score of 1 or above } & N & 166 \\
\cline { 2 - 3 } & $\%$ & 71.0 \\
\hline \multirow{2}{*}{ Minimization/denial score of 0 } & $\mathrm{N}$ & 69 \\
\cline { 2 - 3 } Total & $\%$ & 29.0 \\
\hline \multirow{2}{*}{ Tot } & $\mathrm{N}$ & 235 \\
\cline { 2 - 3 } & $\%$ & 100.0 \\
\hline
\end{tabular}

137 participants who were exposed to CAN were tested for their violent criminal behavior. $P$ value of the 
t-test was determined as $0.995(p>0.05)$. There was no significant relationship between violent criminal behavior and being exposed to CAN.

Table 4: Relationship between Violent Criminal Behavior and Child Maltreatment History

\begin{tabular}{|c|c|c|c|c|}
\hline & & $\begin{array}{c}\text { Violent } \\
\text { Criminal }\end{array}$ & $\begin{array}{c}\text { Non-violent } \\
\text { Criminal }\end{array}$ & Total \\
\hline \hline \multirow{2}{*}{$\begin{array}{c}\text { Not exposed to } \\
\text { violence in the } \\
\text { family }\end{array}$} & $\mathrm{N}$ & 41 & 12 & 53 \\
\cline { 2 - 5 } & $\%$ & 23.0 & 23.1 & 23.0 \\
\hline $\begin{array}{c}\text { Exposed to } \\
\text { violence in the } \\
\text { family }\end{array}$ & $\mathrm{N}$ & 137 & 40 & 177 \\
\cline { 2 - 5 } & $\%$ & 77.0 & 76.9 & 77.0 \\
\hline \multirow{2}{*}{ Total } & $\mathrm{N}$ & 178 & 52 & 230 \\
\cline { 2 - 5 } & $\%$ & 100.0 & 100.0 & 100.0 \\
\hline
\end{tabular}

$\chi^{2}: 0.000$, Degree of freedom: $1, p$ value: 0.995 .

\section{DISCUSSION}

The aim of this paper is to discuss the tendency of male adolescent offenders toward denial of child maltreatment experiences. According to the findings, there are few inconsistencies among the responses to the questions related to CAN. When physical and verbal violence were asked directly by mentioning slapping, pushing, hitting, insulting, and humiliating, number of children responded to being exposed and/or witnessed to violence was 92 , corresponding to $39 \%$ of the sample group. This number increased to 179 , which is $76 \%$ of the sample group, when CAN experiences were asked to the participants in terms of frequency of the violence. Moreover, a total of 146 children, which is $62 \%$ of the sample group, responded when the question was about family member(s) who were exposed to the violence. These results show that there is a noticeable difference between the responses depending on the questions asked directly or indirectly. Such difference is justified by the Minimization/Denial sub-scale of the CTQ. As shown in Table 3, 71\% of the sample group (166 children) has a tendency to deny the violence they were exposed to. Consequently, the difference might be caused by the question type (direct or indirect) and be influenced by the participants' tendency toward minimizing or denying their CAN histories. Some studies emphasize that the reason for children to deny their CAN histories is due to the interview techniques (London et al. 2005). Studies have also suggested open-ended and non-directive questions when interviewing with children who have CAN histories (Mordock 2001).

This study shows that participants somewhat rationalize the violence when they were experience it a few times in a year. They see violence as an acceptable behavior if their parents display it. Participants' responses to the open-ended questions in the demographic information form also support this idea. These responses include some phrases such as "my parents beat me but I know they love me at the same time" or "a rose grows where the father or the mother hits", which is a Turkish proverb; implies that children perceive violence as a normal behavior among family members. The increase in number of denials and the delay in disclosing traumatic behavior as the relationship with violent person becomes stronger are supported by the studies (Christianson et al. 2013; Hershkowitz 2006).

In our study, a total of 166 participants get sufficient scores from minimization/denial scale to support existence of denial among adolescent offenders cannot be overlooked. This finding may clarify the reason behind why the study hypothesis was not supported by diretly asking violence to this particular group. Villano et al. (2004) used the CTQ scale to study women who are forced to work as sex workers in the streets. The study pointed out that $42 \%$ of the sample group minimized or denied violence they were exposed to in their childhood. Denial of violence is also one of factors causing domestic violence to continue. Women expect that violence, will disappear from their life at some point (Sevim and Şaşmaz 2012). Children growing up with parents having this kind of mind-set are more likely to develop similar tendency to deny violence.

According to study by Leander (2010), abuse related questions were asked of children in three different forms; obtaining information through neutral conversation (letting the conversation flow), asking direct questions on the specific moment when the abuse occurred, and asking questions on sensitive information. Children have tendency to reveal the information about abuse when the neutral conversation is utilized. Similarly, in this study, the children disclosed their abuse experience when they were not directly asked about their CAN histories.

CTQ minimization/denial scores were obtained by those who responded "very frequently" to the following items; "there was nothing I wanted to change about my family", "my childhood was perfect", and "my family was the best in the world". These questions are considered as exaggerated statements that can agitate and cause overwhelming emotions of those who respond as they are associated with their traumatic experiences. There is a possibility of choosing the lowest or the highest 
option due to being agitated. This can be considered as a limitation of the scale. It was also not possible to make gender comparison in this study since the entire sample was only male adolescents.

Based on this study, it is recommended that the clinicians doing research on adolescents who have CAN histories should take into account their tendency to deny these experiences. This study also suggests that the clinicians and researchers working with this population should be aware of the denial and accordingly be more tolerant in their helping and research process.

\section{REFERENCES}

Aktepe, Evrim, Sema Kandil and Murat Topbas. 2005. "Suicidal Behavior in Children and Adolescents." TAF Preventive Medicine Bulletin 4(2):88-97.

Bernstein, David P. and Laura Fink. 1998. Childhood Trauma Questionnaire: A Retrospective Self-Report Annual. San Antonio, TX: The Psychological Corporation.

Bilgin, Nursel, G., Fevziye Toros, Handan Çamdeviren, Tayyar Şaşmaz and Ertan Mert. 2004. "Sociodemographic Characteristics of Children with Physical and Verbal Punishment at Home: Prevalence Study." Yeni Symposium 42(3):131-139.

Caykoylu, Ali, Aslihan O. Ibiloglu, Yasemen Taner, Nihan Potas and Ender. Taner. 2011. "The Correlation of Childhood Physical Abuse History and Later Abuse in a Group of Turkish Population." Journal of Interpersonal Violence 26(17):34553475.

http://dx.doi.org/10.1177/0886260511403748

Christianson, Sven Å., Azade Azad, Lina Leander, and Heidi Selenius. 2013. "Children as Witnesses to Homicidal Violence: What They Remember and Report." Psychiatry, Psychology \& Law 20(3):366-383.

http://dx.doi.org/10.1080/13218719.2012.692930

Gil, Eliana. 1991. Healing Power of Play: Working with Abused Children. New York: Guilford

Greydanus, Donald and Joseph Calles. 2007. "Suicide in Children and Adolescents." Primary Care: Clinics in Office Practice 34(2):259-273

http://dx.doi.org/10.1016/i.pop.2007.04.013

Grinberg, Leon. 1961. "Why We Deny." The Psychoanalytic Quarterly 30:118-138.

Haapasalo, Jaana and Juha Moilanen. 2004. "Official and Selfreported Childhood Abuse and Adult Crime of Young Offenders." Criminal Justice and Behavior 31(2):127-149. http://dx.doi.org/10.1177/0093854803261328
Hanks, Helga and Peter Stratton. 2007. "Special Section: On Learning from the Patience. "Clinical Child Psychology and Psychiatry 12(3):341-347. http://dx.doi.org/10.1177/1359104507078464

Hershkowitz, Irit. 2006. "Delayed Disclosure of Alleged Child Abuse Victims in Israel." American Journal of Orthopsychiatry 76(4):444-450.

http://dx.doi.org/10.1037/0002-9432.76.4.444

Ife, Jim. 2008. Human Rights and Social Work. New York: Cambridge.

Leander, Lina. 2010. "Police Interviews with Child Sexual Abuse Victims: Patterns of Reporting, Avoidance and Denial." Child Abuse \& Neglect 34(3):192-205. http://dx.doi.org/10.1016/j.chiabu.2009.09.011

London, Kamala, Maggie Bruck, Stephen J. Ceci and Daniel W. Shuman. 2005. "Disclosure of Child Sexual Abuse: What Does the Research Tell Us About the Ways That Children Tell?" Psychology, Public Policy, and Law 11(1): 194-226. http://dx.doi.org/10.1037/1076-8971.11.1.194

Mordock, John B. 2001. "Interviewing Abused and Traumatized Children." Clinical Child Psychology and Psychiatry 6(2): 271-29. http://dx.doi.org/10.1177/1359104501006002008

Ovacık, Asli C. 2008. "Effects of Domestic Violence on Physically Abusive Behavior of the Male Child." Master's thesis, Institute of Forensic Sciences, Istanbul University, Istanbul.

Sevim, Yelda and Onur Y. Şaşmaz. 2012. Doğunun Aile Içi Şiddete Maruz Kalan Kadınları (Elazığ ili örneği). Uluslararası Katıımlı Kadına ve Çocuğa Karşı Şiddet Sempozyumu (2728 Nisan 2012, Ankara), Bildiri Kitabı II.cilt, s.818-831, Ankara.

Summit, Roland C. 1983. "The Child Sexual Abuse Accommodation." Journal of Child Abuse and Neglect 7:177-193. http://dx.doi.org/10.1016/0145-2134(83)90070-4

Şar, Vedat, Erdinc Öztürk and Eda İkikardeş. 2012. "Validity and Reliability of the Turkish Version of Childhood Trauma Questionnaire." Türkiye Klinikleri Tıp Bilimleri Dergisi 32(4):1054-1063.

Villano, Cherie L., Charles Cleland, Andrew Rosenblum, Chunki Fong, Larry Nuttbrock, Marie Marthol, and Joyce Wallace. 2004. "Psychometric Utility of the Childhood Trauma Questionnaire with Female Street-based Sex Workers." Journal of Trauma \& Dissociation 5(3):33-41. http://dx.doi.org/10.1300/J229v05n03 03

Weeks, Robin and Cathy S. Widom. 1998. "Self-reports of Early Childhood Victimization among Incarcerated Adult Male Felons." Journal of Interpersonal Violence 13(3):346-361. http://dx.doi.org/10.1177/088626098013003003

Widom, Cathy S. and Robin L. Shepard. 1996. "Accuracy of Adult Recollections of Childhood Victimization: Part 1. Childhood Physical Abuse." Psychological Assessment 8(4):412-421. http://dx.doi.org/10.1037/1040-3590.8.4.412

World Health Organization. 2006. Preventing Child Maltreatment: $A$ Guide to Taking Action and Generating Evidence. Retrieved Nov, 222012 (http://whqlibdoc.who.int/publications/2006/ 9241594365_eng.pdf)

\section{DOl: http://dx.doi.org/10.6000/1929-4409.2015.04.05}

(c) 2015 Yalım and Sezgin; Licensee Lifescience Global.

This is an open access article licensed under the terms of the Creative Commons Attribution Non-Commercial License (http://creativecommons.org/licenses/by-nc/3.0/) which permits unrestricted, non-commercial use, distribution and reproduction in any medium, provided the work is properly cited. 